\author{
木匠の斧子について \\ 中国江南の木匠工具に関する研究 その 1 \\ CARPENTER'S AXE AND ADZE \\ Carpenter's Tools in Jiangnan District, China Part 1
}

\author{
山口幸夫* \\ Yukio YAMAGUCHI
}

\begin{abstract}
The purpose of this paper is to make clear the historic outline of carpenter's axes and adzes in Jiangnan district from Ming-Qing era to today.

According to field work and studies of carpenter's manuals Lu Ban jing ets., carpenters have used axes but not adzes.

Axes have been used for hewing logs,pounding joints,driving chisels ,and building ceremonies.
\end{abstract}

Keywords: China, Jiangnan, carpenter's tool, axe, carpentry, Lu Ban jing 中国，江南，大工道具，斧，大工技術，魯班経

1. 研究の目的・方法

中国の木匠工具に関する史的研究は端緒についたばかりで あり、明清代より近代にいたる長江下流域・江南地方の木工 具の概括を論じたものはない。また木匠の作業、工具等の文 献絵画史料も充分整理がなされていない。そこで本稿では現 地での寒地調查、文献絵画史料の調查を行い、明清代より近 代にいたる江南地方の木匠工具の基礎的研究を行った。

第一稿は「賟名」の「釋用器」にならい、オノに関して考 察する1。

本稿では日本語、中国普通話、現地の採取語魚を区別する ため、中国の工具名に相当する日本語をカタカナ表郡し、そ の他は以下の如く表記する。

(1) 中国語普通話は、,でかこむ。

(2) 江南地方で採取した言葉には下線をを引く。

(3)史料に記された用語は「」でかこむ。

(4) 文献名は「」でかこむ。

1.1. 現代のオノに関する実地調查
現地での実地調查は建造物修復現場等での作業の観察、木 匠の工具の採録、木工技術者へのヒヤリングからなり、あわ せて現代の木工技術書の収集、近代に行われた実地調查記録 の分析を行った。

本研究の調查の中心をなすのは、1985年9月から1988年 8 月まで、上海の同済大学建築城市規咱学院に留学期間中、同 学院・関係部門の許可をとっ.て行った実地調查である。

そのうち主要なものは、1987年4月より1988年8月にかけ ての上海市の全国重点文物保護単位（国宝にあたる）豫園の 文化財修復現場、及び以下の窑波 - 紹與 - 揚州 - 蘇州等の江 南地方の諸都市での調查である。

1988年1月21日～1月25日 [䁇波、天一閣（全国重点文物 保護単位) - 稆興、東湖等 ] 1988年5月 12 日 5 月 15 日 [鎮江、揚州] 、1988年3月23日～3月26日 [落州、独州古 建園林公司等]

また北方地域との比較を行うため、北京において 1988 年 6 月26日〜7月4日 [北京故宮博物院] 等の㬰地調査を行った。

* 早稲田大学アジア建築研究会 工修

Waseda Univ. Asia architecture research group, M. Eng. 


\subsection{1. 調查対象の木工技術者}

本調査では建物、建具・家具、彫物、桶関連の主に都市部 で動く木工技術者を対象にした。

これらの木工技術者の名称は近代の上海では〈木匠〉・《末

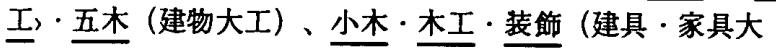
工）、花彫（彫物大工）、円作（桶大工）、草場（型

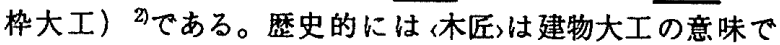
用いられ 、《木工〉は主に家具等の木工工芸技術者を示し た。また一般の人々は大工組織を示す木作も大工の意味で使っ ていだ〉。

また、革命後、各種労働者【人,の名称として「・・I」 という呼び名が一般に用いられたこともあり、現在、大工は 林工と呼ばれるのが一般的である。中国では1950年代以 降、政策によって、都市部において在来の木造構法の住宅等 が建てられなくなり、都市部の、木匠〉の多くは室内装飾、建 具、家具に携わることとなった。このため都市部において建 造物全体に関わるは匠〉は極めてわずかであった。

(以下《匠)についてはく、表郡を省略する。)

1.2. 古代のオノに関する文献資料調查

考古学的文献より鉄製オノに関する出土データを抽出、オ

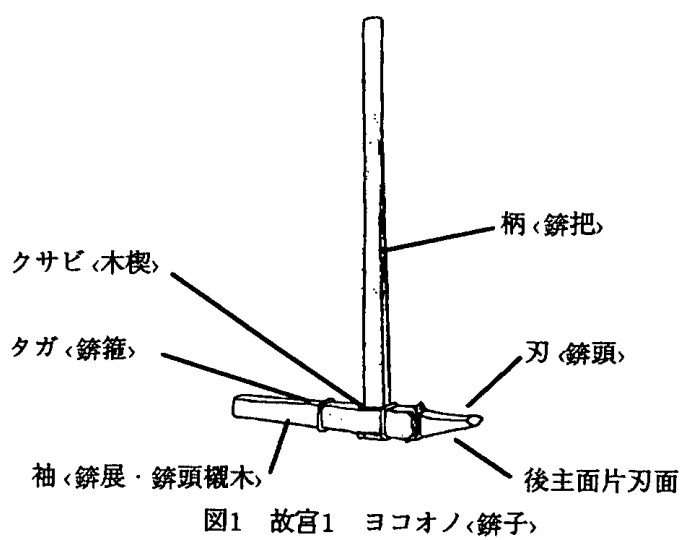

ノの形態等の概略を整理した。

1.3. 古代のオノに関する文觔絵画史料調查

本研究で用いた主要な文献は明代中期に刊行された「魯般 営造正式」(天一閣本) 5、その流れを汲む「魯班経」の、 清末近代䔉州の民間建築技術に関する「営造法原」ク及び 明清代の技術関係書、通俗的類書等である。

「魯班経」は末元代の手法も若干みられ、明清代以降、江 南地方を始め東南沿海地区に流布した。その内容はこの地域 の実際の建築・装飾 ·家具の特性をよく表しているとさ れ ${ }^{8)} 、$ 江南の民間建築の研究に有用な史料である。

\section{4. 既存研究}

中国の工具についてはニーダムJ.Needhamによる先駆的研 究9がある。木工具全般に関しては趙継柱によるもの 漢代の大工道具についての林奈巳夫によるもの ${ }^{11) 、 ま た カ ~}$ ンナ類に関しては孫機による研究 ${ }^{12}$ 名ある。石オノに関し ては楊鸿䰻 ${ }^{13)}$ 、傅靑国 ${ }^{14)}$ 、銀鉄オノに関しては雲翔回の考 古学的研究がある。

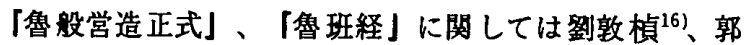
湖生 ${ }^{17)}$ による研究がある。近年のものとしては「魯班経」 の家具に関する王世襄 ${ }^{18)}$ のの、民間の大工技術書の体系 的研究の中で「魯班経」全編の注釉を行ったKlaas Ruitenbeekの研究 ${ }^{19)}$ がある。

江南地方の木工具に関する実地調査は、1920年代のホン メルR.Hommelによる同地方を含んだもの 20)、1934年ごろの

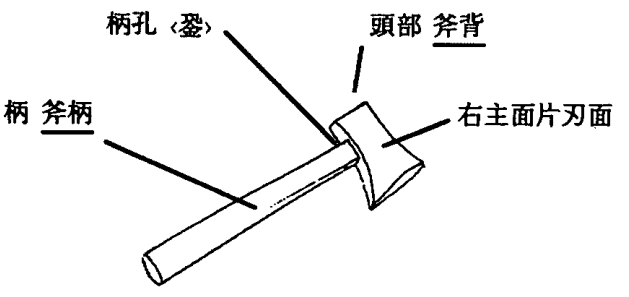

図2 浦東 片刃短柄のタテオノ菒子

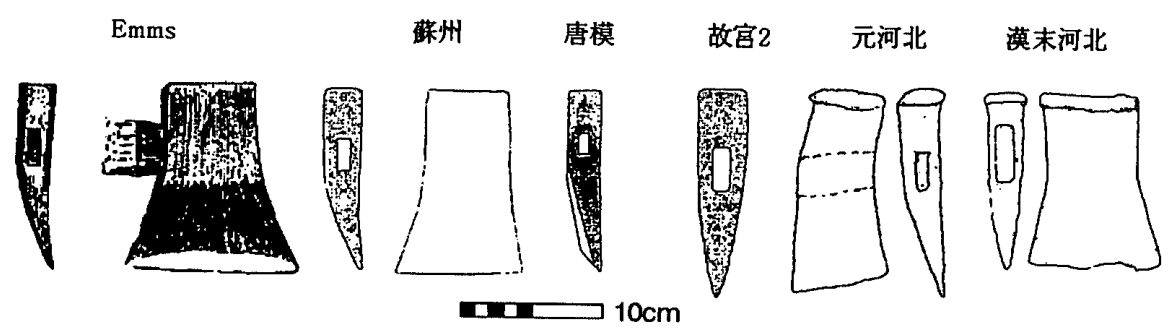

$$
\begin{array}{ll}
\text { Emms } & \text { 片刃 } \\
\text { 触州 } & \text { 片刃 } \\
\text { 唐模 } & \text { 片刃 } \\
\text { 故宦2 } & \text { 两刃 } \\
\text { 元河北 } & \text { 片刃 } \\
\text { 熯末河北 } & \text { 两刃 }
\end{array}
$$

図3 木匠の茎（斧身）

(Emms Vol.13, No.3,pp97) Fig28.29.

落州（市内で購入） 1988/7/23 より作図

安微省唐模 (木工：安微省唐模）1990/10/20 上り作図

北京故富 (大木·河北省新河) 1988/6/29 上り作図

河北磁県南開河村（「考古」1978.11、p394）図10-3

河北定県北荘漢基（「考古学報」1964.12、D134) 図7-2

郡号、表郡法は各图版、表とも共通。 
エムスA.Emmsによるもの 21 がある。また本稿に関連する民 族学的調查として、染木煦による中国東北部の生産工具に関 する調查 ${ }^{22 j}$ 、浅川滋男による江南地方の明清代住宅及び 「魯班経」の版本調査等がある ${ }^{23) 。 ~}$

近年の中国における木匠工具の調査としては、竹中大工道 具館による中国各地での調查と収集 ${ }^{24)}$ 、石村真一による福 建等での鉋類の調查がある ${ }^{25) 。 ~}$

本稿に関連する日本の大工道具については木工具全般に関

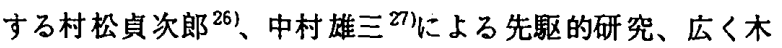
工技術全般の中でオノについても考察した成田寿一郎 ${ }^{28)} の$ ものがある。個別の大工道具については、オノに関して鉔治

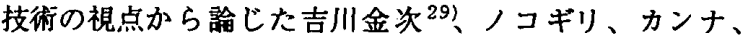
ツチ等に関する星野欣也 ${ }^{30 !}$ 、沖本弘 ${ }^{31 !}$ 、渡圐晶 ${ }^{32}$ ，土屋安 見及び石村具美 ${ }^{331}$ によるものがある。

\section{2.・オノ関する用語}

本稿ではオノに関する用語を考古学の用例に準じ ${ }^{34) 、 以 ~}$ 下のように記す。またオノに関する用語の中国語名称につい て実地調査、現代の木工技術著より整理した ${ }^{35)}$ 。

(図1 図2 参照)

2.1. ダテオノ：ヨコオノ（チョウナ）

刃線が柄とほほ並行するタテオ人、刃線が柄と直交するも のをヨコオノと記す。中国語ではタテオノを希子、、コオ ノを锌子〉と呼んでいる。

2.2. 刃

刃の形態が左右対称なものを両刃、非対称なものを片刃と 記す。中国語では一般に両刃を(双刃、、片刃を(単刃)と呼ふ。

2.3. 算身

斧身の刃の側を刃部、その逆側を頭部と郡す。斧身の刃の 面を含む面を主面、逆を㒋面と呼ぶ。算身の柄を握って楎え て、左右をそれぞれ左面、右面、手前近くを前面、向こうを 後面と記す。片刃の場合、その勾配の强い面を片刃面と記す。

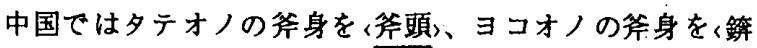
頭〉と呼び、算身の頭部を齐背・往項〉と呼ふ。

2.4. 柄

曲がって連続した柄を㮏柄、直線状の柄を直柄と記す。斧 身を柄に直接固定せず、斧身をはめた部材を柄に固定する場 合は、この部材を袖と記す。（㕍柄ともよばれる）

現代中国語ではく柄〉は器物に付けた唡の意味で用いられる か ${ }^{36)}$ 、古代中国で「柄」は䆑の柄を意味した ${ }^{37) 。 こ う し た ~}$ 㐎の柄の名称として、後漢の許慎撰「説文解字」には 「圆: 柯・柄」が記されている38)。

現在タテオノの直線状の直柄は一般に(齐把)・齐柄)と呼 ばれる。ヨコオノの柄はく錡把〉と呼ばれる。錛把には㮏柄 のものと、直柄に袖(喯展)、錛頭䞋木〉を付けたものがある。 2.5. 条身の固定孔

斧身を貫通じた柄をさし込む孔を柄孔、柄孔のある齐を穿
表1 現代中国の木匠のオノの名称

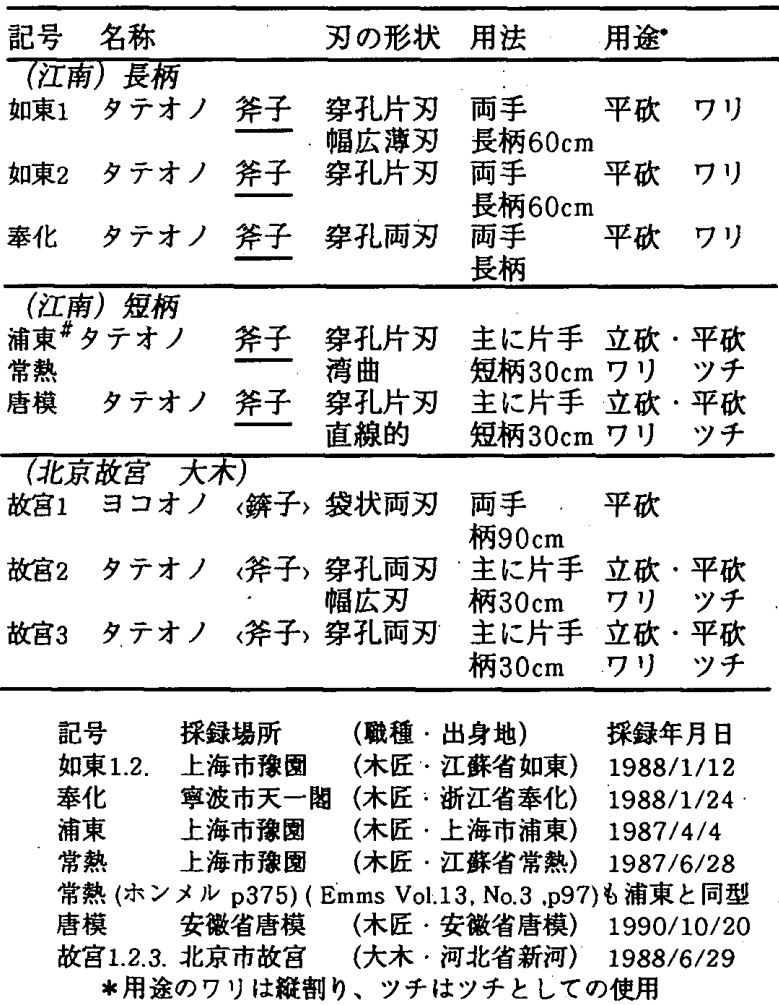

記号は各図とも共通

孔茲と記す。柄をさし込むソケットのような袋状の部分を柄 袋、柄袋のある斧を袋状斧と郡す。

古代中国において「䡃」は円形の唡袋を味したが、漢代 には方形柄袋をも呼ふようになる ${ }^{399}$ 。現代中国語では柄袋、 柄孔いずれをも(䡃)と呼ぶ40)。

日本では柄孔を「ひつ」とよび「柲」の字をあてる場合が ある。しかし現代・古代中国語で「柲」は、古代の兵器の柄 の意で、柄孔 : 柄袋の意はない411。

\section{3. 現代のオノに関する実地調查}

上海を始めとする江南の諸都市と北京で行った実地調查で 探録したものを表1に分類した。また、主要な养身の形態を 分析するため、実地調査、及び後述の出土データより、同縮 尺の図を作製した。（図3 参照）

\section{1. 江南のオノ}

調查で確認できた江南の木匠の《茲子〉の編成は加工用の長 柄と短柄のタテオノのみで、ヨコオノは用いられていなかっ た。上海、萱波等では原木の柱への加工や梁材加工に(斧子、 が使われていた

柄父把〉は一般に木匠の自製で、はつり用の禹手持ちの長 柄（一般に50-60 cm）と主に片手持ちではつり用だけでなく 

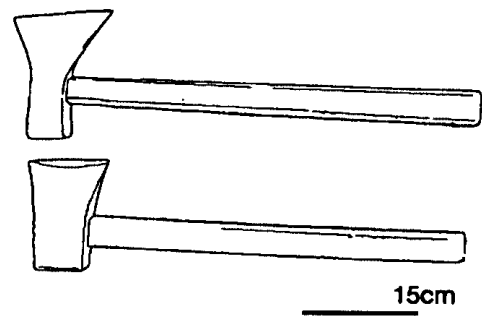

因4 如東 長柄の迸子、幅広薄片刃と片刃 柄 $60 \mathrm{~cm}$

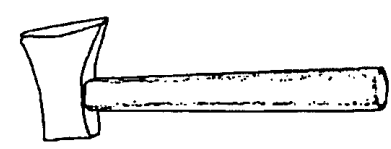

図5 浦東 短柄の谽子) 片刃 柄 $30 \mathrm{~cm}$

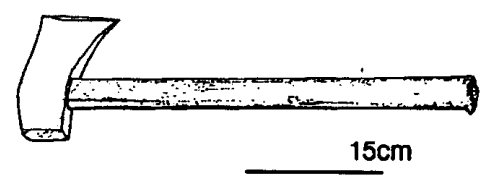

図6 唐模 短柄の(斧子) 片刃 唡 $43 \mathrm{~cm}$

ツチとしても使う短柄（一般に $30 \mathrm{~cm}$ 強）がある。近代蘇州 の木匠技術について書かれた「営造法原」には「柄一尺八寸 $(49.5 \mathrm{~cm})\rfloor と あ り{ }^{43)}$ 、筆者が蘇州で調查した䇣身は重さ 920gであっだ4ことを考え合わすと、一尺八寸あたりが両 手持ち、片手持ちの境目と思われる。

木匠が用いるこれらの長柄や短柄の齐子、の蕉身には方形 柄孔釴〉があり、両刃のものと片刃のものがある。両刃はは つりと释方向に割るのに、片刃ははつりに適する。

(図3 参照)

江南の短柄の军子、については管見のもの、Hommel、 Emmsが記録したもののすべてが片刃である。また上海で 編まれた木工技術書のタテオノの説明には片刃の図が

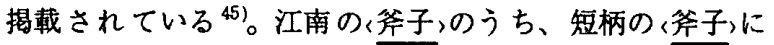
ついては「茶子、は江南では片刃、北方では両刃」といった 木匠間の俚謗どおりと言えよう。

\subsection{1. 長柄の (条子)}

両手持ちの長柄の斧子〉の刃は両刃、片刃が観察された。 図4は如東の木匠の使っていた長柄の斧子っいずれも片刃

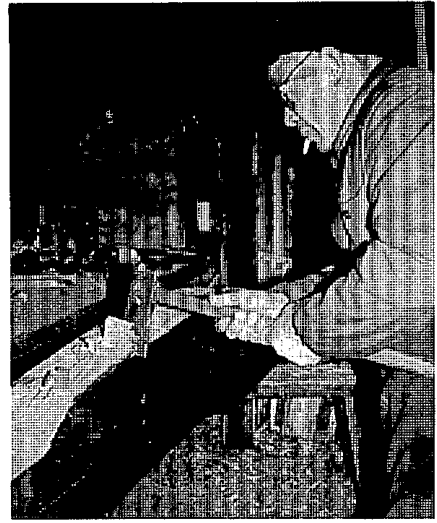

図7 奉化 長柄の茎子、でのはつり平斫， 〈条発〉上で梁の加工

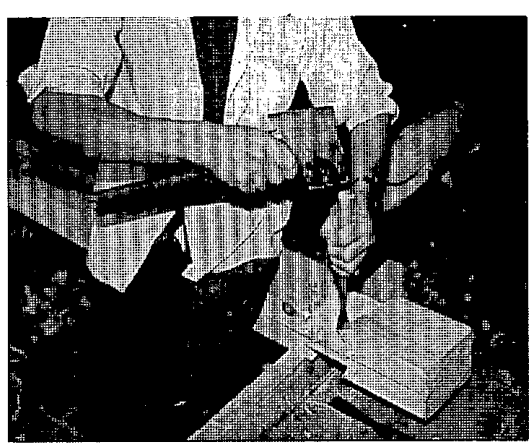

図8 常热 斧子)で整子)を吅く 条発)上の桁の加工（走廊の製作）

で、ひとつは特にはつり仕上げに適した幅広の薄刃である。

長柄の、算子、は大きな部材の水平方向の面をはつる(平斫) に使用する。《平斫〉は2台の作亲台に部材を水平に差し湾 し、両手（右手が斧身に近い）で柄を握り、斧子、を水平方 向に振ってはつる。作業台としては丸材を三脚に組んだ、末 馬、46)、背もたれのないベンチ(条発〉・板発〉初がある。片刃 の場合、右主面片刃面が材にあたる。図7は寧波市天一閣で ベンチ《条発〉の上の古材を梁に転用するため、長柄の両刃 (斑子でははっているもの ${ }^{48) 。 ~}$

3.1.2. 短柄の（军子)

短柄の、㭚子、は木匠のよく使う主要な工具で49)、材のはつ り、くさび作りに用い、また齐身の頭部齐背をツチとして使 用する。

(図8 参照)

現在の江南で典型的な短柄の斧子〉は右主面片刃面の片刃 で、主面は刃部に向かって末広がりで、刃は左に反っている。 左主面に鋼が鏗接してあり、右主面の側を研いで刃をつける。

以下はいずれも典型的な江南の片刃(希子)で、図3-Emms 
は近代の調査でEmmsが記録したもの、図2、図5は同様の片 刃で、上海木匠の主流をなす浦東木匠のもの。図3·综州は葆 州で購入したもので家具や小規模な造作に使うものと思われ る。

片刃には主面上部が凸型のものもある。図3-唐模、図6は 安微省鮧県唐模で観察された片刃で、右主面は曲面ではなく 直線断ちされた2平面から構成されている。

(1) はつり

短柄の父子でのはつり作業には左手で小部材を持ち、右 手で毫子、を振り、垂直方向の部材面をはつるく立斫〉がある。 〈立斫〉では片刃の左主面、平らな側が材にあたる。このた め片刃の立斫〉では小さい角材が特に効率的に作られる。 短柄の斧子〉は両手持ちして、平斫〉も行う。片刃の場合、 湾曲した右主面が材にあたる。上海市豫園では(馬、に直いた 原木を両手持ちした短柄の片刃斧子〉で16角にはつり,その 後カンナ刨子、で円柱に仕上げていだ0)。

(2) クサビ作り

日本の大工銭は木っ端を割ってのクサビ作りに使わ れるが51)、中国の短柄の父子もりサビ作りに使われる ${ }^{52)}$ 。

クサビは、父子、で小材を割ったものと、小材を直接ノコ ギリ引きしたものがあり、上海市豫園の文化財修復現場では、 クサビはノコギリで作っていた ${ }^{53) 。 ~}$

(3) ッチとしての使用

江南の木匠はノミを吒くのに専ら短柄の藮子、を使ってい る。齐背は丸く中高になっていて木を㙁つけない。ノミを叨 く場合は柄元（齐身に近い部分）、にぎって行う。図8は上 海市豫園で常熟の木匠が短柄の、斧子、でノミ《整子、を吒いて 桁のホゾアナを加工しているもの

タテオノは小部材を打つことにも使うが、军背部分は鋼 ではないため金属は打たないという5)。

3.2. 北京のオ,

北京故宮の 大木)（構造部分を受け持つ木匠）は、両手持

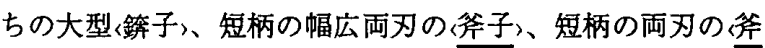
子、を使っていた

3.2.1. 長柄の镜子

中国で現在使われているヨコオノ錛子、は、木工技術書に よれば方形柄袋ので脉柄袋状オ八、直柄に袖付袋状オ人、直 柄で斧身がすべて鉄製のツルハシ状のものの3種があるらク。

このうち北京の調査で確認できたものは2種で、いずれも 雨手持ちの長柄である。故宮では直柄に袖付のもの、王府 の修復現場で直柄のツルハシ状のものが使われていた ${ }^{58)}$ 。

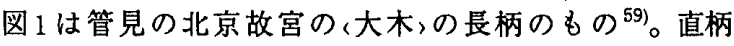
〈錛把にホゾを設けて木製の袖錛展をくさびく楔ととめして

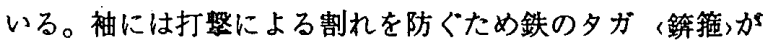
はめられている。袖の先端に方形柄袋の斧身(畬頭をはめる。

刃は後主面片刃面で、両手で大きな面や、大梁など曲面 をはつる場合に使用する。地面においた承平方向の部材面を はつる(平斫)の作業姿勢は日本のそれに似て、部材の上に立

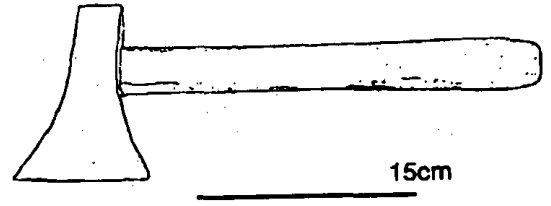

図9 故宮 2 短柄の(斧子) 両刃 柄 $30 \mathrm{~cm}$

ち、右足を前に左足は後ろに丁字に構え、両手で錛子、をク ワのように振り下ろす。

短柄のものは筆者は未見であるが、近代の調查や技術書に よれば滕柄、直柄に袖付やッルハシ状のものがあり ${ }^{60} 、$ 水 平方向の部材面をはつる (平斫)のほか、(立矿〉も行う ${ }^{61) 。 ~}$

筆者の江南の実地調查ではヨコオノは見られなかった。ま た近代の Hommel やEmmsの調査でも、江南において建築 に関わる木匠のヨコオノは観察されず62)、「営造法原」にも 記載されていない63)。現代の木工技術書にも一般の建筑現 場ではあまり使われず、農村部で使われるとある ${ }^{64) 。 お そ ~}$ らく、ヨコオノは大がかりな原木の加工に使われ、商品化木 材をあまり使用しない農村部や、曲面を持つ大梁等の部材を 扱う宮殿、寺院などの修復現場で使われていると考えられる。 3.2.2. 短唡の(蕉子)

北京においては短柄の彥子、は両刃しか見出せなかった。 大木達も自分たち北方の木匠は両刃の盾子、使うと語っ ており、北京、河北等では一般に両刃を使用すると思われる。

図3-故宮2及び図9は、北京故宮の〈大木,が用いていた両刃 の短柄の、养子っのうち幅広のもの。ノミを吅くなど用法は江 南とほほ同じである。

4. 古代のオノに関する考古学的文献資料調査

ヨコオノで現代のものに近い、後主面片刃面方形唡袋の 状オノとしては戦国時代中期の膝柄の銅製ヨコオノが知られ ている ${ }^{65)}$ 。

現在のタテオノのように鉄製の方形柄孔穿孔茾のうち、両

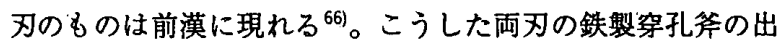
土品は図3 3 漢末河北の定県北荘漢墓 ${ }^{6 \pi}$ 、金代の吉林輯安県 ${ }^{68}$ 、 元代初期と思われる江萑揚州市のもの ${ }^{68}$ などがある。

現代のものに類似した片刃の鉄製穿孔齐は金代の吉林輯安 県発掘のもの ${ }^{69)}$ 、図3·元代河北の磁県南開河村の木船とと もに出土したもの ${ }^{70)}$ な゙がある。(図3 参照)

\section{5. 古代のオノに関する文献絵画史料調查}

明代のオノについては「王公忠勤録】の「採木之圆」から、 伐採用タテオノ、加工用のヨコオノ、ノミを叨いている短柄 


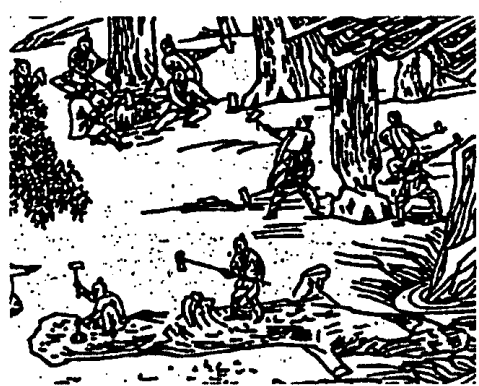

図10 明代の伐採紊、ヨコオノ、ノミを叨く短柄の斧 【王公忠勤録」「採木之圈」（J。ニーダ、10巷、 p336）

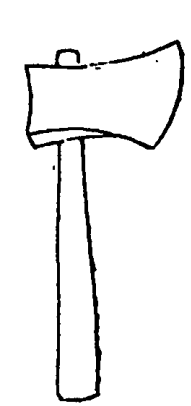

图11「管」

「展菑」集之四 25

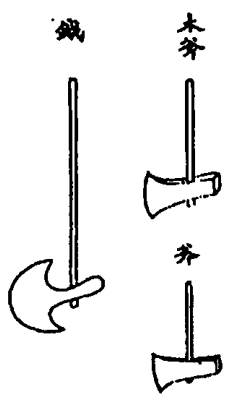

図12「钱柊莽」 河工器具圆説」巷三 16
のタテオノの使用が伺える ${ }^{71)}$ 。（図10 参照)

5.1. 明清代のヨコオノ

図10の「採木之圖」のヨコオノは大型の袖付の両手持ち

用で、地面に垵かせた材を立ってはつっている。

清末、1905年刊行の「欽定書經圖説」の「有備無患巻圖」

にはカンナがけ用ベンチの下にヨコオノが見られ72加工用

ヨコオノが使われたことがわかる。（図16 参照)

5.2. 明清代のタテオノ

前揭の図10の「王公忠勤録」の「採木之圖」には、両手 持ちの伐採用タテオノ、片手持ちのタテオノも描かれている。 また長柄の伐採用タテオノは「欽定書經圖説」の「導山副

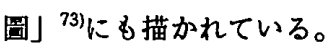

管見によれば、明代のタテオノの絵画史料で古いものは、 王禎「農書」（1313年成稿、1530年刊）に見られる。「農 書」には、幅狭厚刃の伐採用タテオノ「樵䆑」と幅広薄刃の 桑の枝を払うタテオノ「桑斧・斫㜪」の図と説明があり、

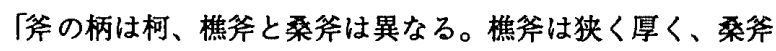
は広く薄い」「斫㐎桑斧なり。扁平な刃で樵茲と異なる」と ある74)。(図11 参照)この図は「三才圖繪」、「古今図 書集成」にも引用されている75)。また宋応星「天工開物」 の1637年の初版には、銅鉄の刃を付けた穿孔希の製法が曹 かれている76)。

清末のオノに関しては、嶙慶「河工器具圖説」 7 (1836
年刊行)に詳しい。自伝の「鸿雪因縁圖記」(1849年刊)

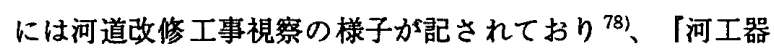
具圖説」の河岸工事の工具についての郡述は実地に基づいた と思われる。その中に大型のタテオノである「銭」、長柄の 幅広刃のはつり用と思われる「木爻」、小型の片手持ちと思 われる「命」が描かれている79)。（図12 参照)

5.2.1. 短柄のタテオノ

「魯班経」に描かれたオノはすべて片手持ちに適した短柄 のタテオノである。短柄のタテオノは「魯班経」の木工具が 描かれた図版 21 点の内 14 点に見られ、明代でも木匠のよく 使う身近な工具であったことを伺わせる。

「魯班経」にみられるオノの斧身は末広がりで、研いだ刃 が図13には左主面に、また図14には右主面に描かれている ことから両刃と思われる。

こうした短柄のタテオノは「魯班経」や前揭の図10の 「採木之圖】から、はつり、ノミを叨く、クサビ作りなどに 使われたと考えられる。

(1) はつり

「魯班経」には立砍〉と平砍〉の図がある。図13(立砍〉で は現在の用法と同じく、左手でもった材を右手で持ったタテ オノではつっている ${ }^{80)}$ 。図14 (平砍〉は木馬」 ${ }^{81)}$ 上の原木 加工で82、図7に見られる現在の用法と同じく両手ではつり 加エしている。

(2) クサビ作り

「河工器具圖説」の図12の「算」に相当すると思われる 「阵算」は「小棒からクサビ㭈を雨（打ちふるい落とし作 る）のに用いる」と記され、短柄のタテオノはクサビ作りに 使われたと思われる83。

「魯班経」にはクサビ打ちした丸太をオガで挽く下部に才 ノとクサビが置かれている図があり、丸太から板を婏くとき のクサビ打にタテオノが用いられたと思われる ${ }^{84)}$

タテオノがクサビ作りから丸太へのクサビ打ちといった一 連の作業に用いられたと考えられる。

(3) ツチとしての使用

先にあげた漢代の斧、元代の南開河村の希はいずれも頭部 が平らでつふれていることから（図3 参照）、ツチとして

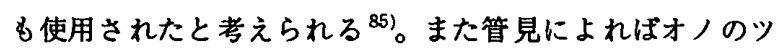
チとしての使用を描いたと思われる最古の絵画史料は、漢代 嘉祥県洪山の画像石である ${ }^{86)}$ 。車作りの図で片手持ちの夕 テオノと思われるもので、ノミを吒く様子が描かれてい $ろ^{87 \%}$ 。

\section{(a) 部材を打つ}

先に挙げた「河工器具圖説」には「木㐎」の横にキッチ 「木榔頭」の図を揭け゚、「鉄笑で埽（讙岸用に茎や枝を縄で 絊り円筒状にしたもの）を打つと縄を切る恐れがあるため、 木榔頭で打て」と記している ${ }^{88)}$ こうしたことから明清代 に部材をオノで打つことは広く行われていたと思われる。

こうした使用法として「薢班経」には短柄のタテォノでッ 


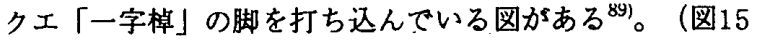
参照）王世襄によればツクエ「一字棹」のホゾ夾頭棒、は

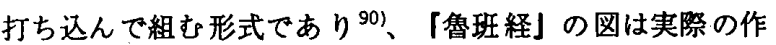
㮍を写実的に描写していることがわかる。また前揭の図16 の「有備無患卷圖」には車輪を作るのにタテオノで打つ様子 が描かれている。

(b) ノミを吒く

タテオノでノミを吒く明代の絵画史料としては、前揭の図 10「採木之圖」がある。「魯班経」にはタテオノでノミを 吒いてウマに置いた材のホゾアナ加工（図17 参照）やべ ンチ「板発」91においた梁の加工（図18 参照）の様子が 描かれている。図18においては、図8の現代の木匠のように 柄の聯身に近い部分を握ってノミを吅いている。

5.3. 建桑儀礼での使用

\subsection{1. 「起工」}

「魯班経」において唯一のヨコオノの使用を示唆する部分 は、建築儀礼に関係する「起工架馬」にある。日本の建築儀 礼の「木造始」でヨコオノで材を打つが92)、「魯班経」の

「起工架馬」には「歩柱を馬に安置し、仕事を始めるに当 たって鉫（ヨコオノを指すと考えられる ${ }^{93)}$ )を翻し内向き

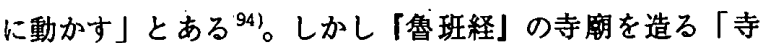
観庵堂㾰宇式」、款物倉を造る・「建造禾倉格」では、いずれ もタテオノ「斧」を手にして柱の加工を始める記述と図か涀 られる ${ }^{95)}$ 。魯班営造正式」にはヨコオノの語句、図版は見 られない。

\subsection{2.「打つ」}

「可は斧柯、柯枝をもって祝䘠器をうち析願の成就をせま る。」ことであり 、「周礼」「考工郡」には「戈をもって 四方を打ち魅䗁を駆逐する」と記されているのクように、オノ は古代より儀礼具として用いられてきた。

日本の建築儀礼の「立柱」、「上棟」の儀礼はツチを使う が98、中国の古代においても「發桘」（柱梁を組む）、「上 梁」(上棟) ではツチが使用されたと思われる ${ }^{99) 。 し か ~}$ し、明代以降の大工技術書、通俗的類書にはこうした「發 桘」、「上梁」等の儀礼の際ツチにかわってオノが使用され たとも考えられる即述が散見される。

日本の「立柱」においては各柱を桘で打って回るが100)、 明代の黄一風の「宅法全書」には、木匠の呪いを泼う法とし て「匠に仁が無く、主人の待遇がもし薄いと、則ち人物魔物 の絵を成し柱のほぞあな、桁のほぞあなに蔵し呪う、・・・ 道士が斧をもち各柱をあまねく打ち大声で新る。」と即され ている ${ }^{1011}$ 。

現代の江南農村の「上梁」儀礼は「置安（宴席を設け、三 牲を供え、上梁文をとなえる）叫梁・登高（木匠が鋸、尺等 の工具を手に吉語を唱えながら梁にかけた梯子をのはる）」

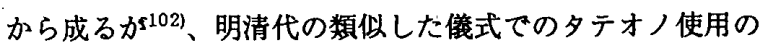
記述や伝承もある。

明末清初に「魯班経」に付加された ${ }^{103)}$ 【秘歌仙機」には
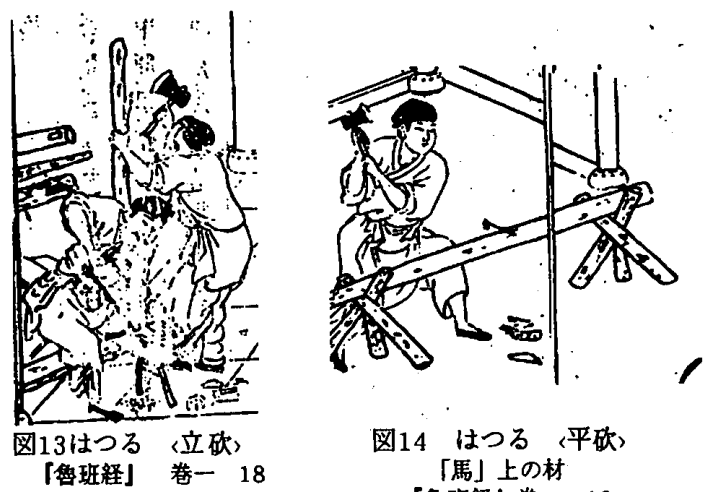

$$
\begin{gathered}
\text { 图14 はつる (平砍) } \\
\text { [馬」上の材 } \\
\text { 「魯班経」卷一 } 16
\end{gathered}
$$
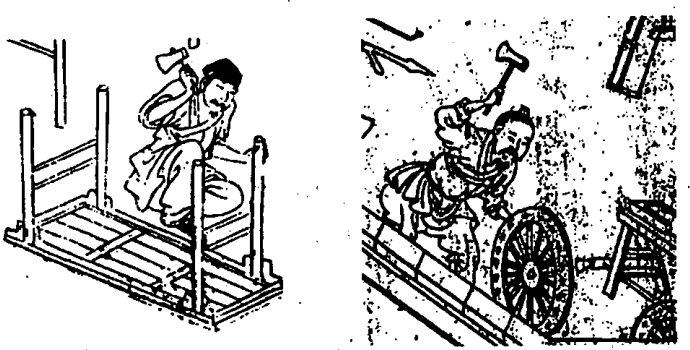

困15 部材を叨く ックエ「一字棹」の脚を租む。 「魚班程】卷二 22

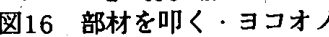
車作门「有沿無患巻圆」

【剑定書程圆説】尞十七 22

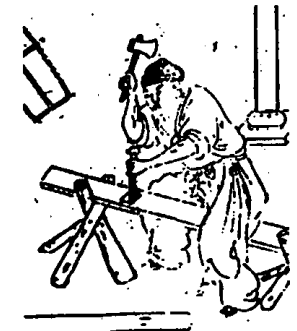

图17オノでミを吸く 「馬」上の材のホソフナ加工 「然班経」卷一 28

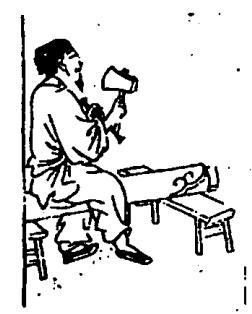

図18オノでノミを叨く 「板瑟」の上の梁の加工 「鲁班程】巻二 24

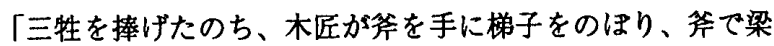
析を3度たたき、天開の祈りを念じる。」 ${ }^{104)}$ とある。

また南方より北京に赴いた木匠の間には「太和殿の上梁の 時に梁が扔さまらす、とっさに雷発達が梁にのほり斧で打っ ておさめ、その功により帝から工部営造処の長班を栜受した」 という伝承がある105)。

\section{6. 結論}

明清代より現代に至るまで、江南の木匠は主にタテオノを 用いてきた。特に末広がりの刃をもつ短柄のタテオノは、は つり・クサビ作りだけでなく、希頭をツチとして、ノミを吅 く・部材を打つ等の多様な用途に使用されたと考えられる。

そうしたタテオノの中で、小材加工用に特化した片刃短柄 
のタテオノは出土データ等から、末元代には普及していたも のと推定できる。

江南の民間建築の木造構法は小断面の部材からなり、はつ り・荒削り加工にはヨコオノよりもタテオノの方が効率的で あったと考えられる。また、手工業の発達による室内装飾・ 建具・家具木匠の技術的発展が、小材加工に適したタテオノ の普及を促した可能性がある。これらは、明清代に中国にお ける先進地域として商業・手工栄に卓越した江南地方の民間 建築生産技術の特徴を反映したものといえよう。

本稿で展開した基磷的研究から、明代江南の建築現場にお いて、タテオノがヨコオノにとって替わった歴史的変化を推 定できよう。短柄のタテオノはツチとしても使用できる多面 的機能とともに、儀礼具としての強い象徽性をあわせ持って いた。このため実用面だけでなく、建築儀礼の儀礼具として も、短柄のタテオノは短柄のヨコオノにとって替わったと考 えられる。ヨコオノは大型化し、伐採現場、商品化木材をあ まり使用しない農村部、大断面の特殊な部材加工を要する宮 殿、寺院等の現場での使用が主になったと考えられる。 以上の歴史的経稦をより実証的に明らかにするためには、 さらに詳細なオノに関する調查とともに、明清代の木材商品 化と原木加工の分業、木材不足に対応した小断面の流通木材 による木造構法の普及、充分な強度を持ったタテオノ・ヨコ オノの鍛造技術の進展、オガによる板材加工の普及等につい ての検討が必要だが、今後の課題としたい。

\section{謝辞}

実地調査にあたっては同済大学の陳従周名誉教授、指学教 官の王稆周教授から御指導を受けただけでなく、各地での調 查の機会を与えていただいた。神戸大学の重村力助教授には、 安微省微州地区調查の機会を与えていただいた。盯団法人竹 中大工道具館には大工道具研究会において研究交流の場を設 けて頂いたばかりでなく、収蔵品の閲覧をさせていただいた。 そして上海、䔉州、察波、北京を始めとする各地の木匠の 皆さんは日本の若者を歓迎し親切に御教授下さった。 記して謝意を表す。
註

1)「释名」に䒨とは甫、甫とは始めの意なりとある。劉熙「释名

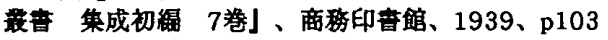

${ }^{2)}$ 上海市豫園（木匠・上海市浦東）87/12/1 6代綂いた木匠 J 氏 からのヒヤリング。

3)「魯般営造正式」や「魯班経」にも「木匠」が記されている。 踈従周序「明魯般営造正式】上海科学技術出版、1988、（天一閣 本影印本) [魯般営造正式、21] [鲁纴経、巻一 1.10.11.37.] (内閣文庫所藏) 詳しくは後述。

4)清末近代の木匠、木作の用例は（江蘇博物館䋵「江萂省明清以来 碑刻資料選轉」三䁬、1959、p82）の大エギルドの碑などに見ら れる。

${ }^{53}$ 民間の大工技術者として現存する最古のもの。前揭［魯般営造正 式]（察波天一閣所藏）

郭湖生「魯㺲経評述」(中国科学院自然科学史研究所䨋 「中国古代 建娼技術史」科学出版社) pp541-544、1985、pp541-542

6)【魯班経」の最古の版本は明萬歴年間の「魯班経匠家鏡】（国家 文物 局所葴)でがあるが欠損が多い。より整ったものは、明末

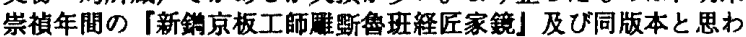

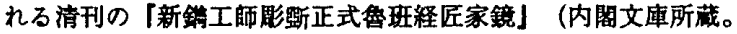
以下「魯玨程内閣本」と記す)である。本稿では「魯旺経内閣本」 を底本とした。

7)代々工匠であり、晚年魯歪会会辰をつとめた姚承柤 (-1939)の 所蔵史料を張至用等が整理䋧基。姚承柤 原著 張至㓮 增編 「営造法原第二版」中国建築工業出版杜、1986

8)前揭［郭湖生、1985、p542]

${ }^{9)} \mathrm{J}$. ニーダム「中国の科学と文明 第8巻」思索社、1979

10)趡継柱「簡锬中国古代建築施工工具」「科技史文集」第 7 轉、 pp153-164、1981.6.

11) 林已奈夫「漠代の文物」京都大学人文科学研究所、1976、 pp286.291

12)孫機「我国古代的平木工具」「文物」松337期、pp70-76、 1987.10.

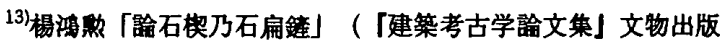
社)、pp59.70、1987

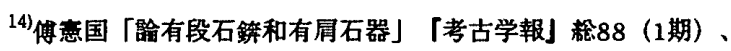
pp1-36、1988.1.

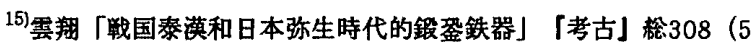
期）、 $\mathrm{pp} 453 \cdot 464.403 、 1993.5$

16)劉敦楨「明魯般営造正式鈔本校読記」「中国営造侥刊」 pp162 164、第6巻、第4期、1937.6. p11

劉敦楨「鲁班営造正式」「考古」棯136号（第2期）、pp7-11、 1962.2 .

17 郭湖生「関于魯般営造正式和售班程」「科学史文集」第7輯、 pp98-105、1981.6. 及び 前揭［郭湖生、1985］

${ }^{18)}$ 王世襄「明式家具研究」南天書局、1989

${ }^{19)}$ Klaas Ruitenbeek : Carpentry and Building in Late Imperial China . EJ Brill ,1993

${ }^{20)}$ Rudolf P. Hommel : China at Work、Jhon Day、 1937

R. ホンメル著 国分直一訳「中国手工莱誌」法政大学出版、1992

${ }^{21)}$ Alfred Emms:The Practice of Joinery and Carpenter amongst The

Chinese of The Yangtsze Valley.The China Reconstruction \&

Engineering Review, Vol.13.No.2,pp4555,1937.2.

Vol.13,No.3,pp96-101,1937.3. Vol.14,No.1,pp25-32,1937.4.

22)染木 煦【北満民具採訪手記】座右宝刊行会、1941 
23)浅川㳊夫「住空間の民族誌」「国立民族学博物館研究報告」 11巻3号、pp669-779、1986.3.

24) 1991 年か594年にかけて4次にわたる調查。竹中大工道具䬼䋧 「竹中東方道具見闒録」竹中大工道具館、1994、p2

${ }^{25)}$ 石村真一「結桶・結樽技術の発達についてその 2」「郡山女子 大学付属高校紀要」2号、pp1-89、1993.6.

${ }^{26)}$ 村松貞次郎「大工道具の歴史」岩波、1973

${ }^{27)}$ 中村雄三「図説日本木工具史」新生社、1974

${ }^{28)}$ 成田寿一郎「日本木工技術史の研究」法政大学出版、1990

${ }^{29}$ 吉川金次「突・堅·鉋（ものと人間の文化史51）」

法政大学出版、1984

${ }^{30}$ 星野欣也、平瀑一雄、渡戛晶、土屋安見「わが国中世のいわゆる “术の葉型鋸”について」「竹中大工道具館研究紀要」第1号、 ppl-13、1989.3.

${ }^{31)}$ 沖本弘「大工道具の凃刃と砥石に関する研究」 「竹中大工道具館研究紀要」第 1 号、pp14-29、1989.3.

32)渡邊晶「近世の建築用の柏について」 「竹中大工道具館研究紀要」第3号、pp17-56、1991.4.

${ }^{33)}$ 土屋安見、石村具美「「六道桧」の大铝」 「竹中大工道具館研究紀要」第3号、pp1-16 、1991.4。

34)佐原真「䆑の文化史」東京大学出版会、1994 等上り整理。

35)以下の木工技術書のオノについての解説を参照。 建築安装技工学校土建木工工芸学編集組「建娼木工工芸学」 中国建築工業、1981

王寿華「建築木工」山東科学技術出版杜、1985

劉殷样「木工入門」河北人民出版社、1985

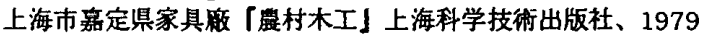

井慶升「清式大作操作工芸」文物出版、1985、

36) 「斧柄。引伸為器物的把儿」漢語大詞典㜊輯委員会漠語大詞典 編䇣処「漠語大詞典 5巻」漠解大詞典出版社、1990、p902

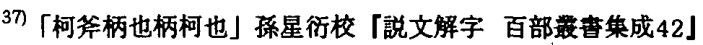
暳文印费館、1965、巻6上7

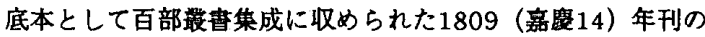
孫星衍校の平津館本の影印を用いた。

38)前揭 [説文解字、巻6上 6.7]

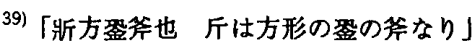

前揭 [説文解字、巻14上 5]

40)前揭 [漢铻大呞典 6巻、p1249]

${ }^{411}$ 木棒を芯に周囲に割竹や木片を麻䄳で巻き付け渿で固めたもの で戦国時代初期等の出土品がある。成東「中国古代兵器図集」 放軍出版、1990、p71.73 林海晋「戦国細木工梅接合工芸研究」 中文大学出版社、1981、 068

${ }^{42}$ 渡廊 (走廊) の円柱の作。上海市豫園（木匠・江葆省常熱） 1987/4/15 梁の加工。寗波市天一閣（木匠·浙江省奉化）

$1988 / 1 / 24$

43)前揭［姚承柤、1986、p88］

44)籍州（市内で睡入） 1988/7/23

45)前揭 [ホンメル 、1992、p375] 図350前揭 [Emms、 1937.3.pp96-97］上海地方で編まれた木工技術蓄は前揭［上海 市㚳定県家具厥、1979、p16.31]を参照

\footnotetext{
46)木馬 寧波市天一閣（木匠·浙江省奉化県溪口区）.1988/1/24

477前揭 [王世襄、1989、pp33-34] は歴史的なベンチ類の枪称を 「長発」とし以下の三種に整理している。

1.「条」大小長短あり、よく見る日常用。
}

「板等」小ふらりで北宋時代すでに定型化されたもの。

「大条器」大ふりで、天板が厚く人が座るほか器物をのせる。

「門垡」大型のもの大門の通路で使用する。

2.「二人眥」長三尺、幅広で二人座り。南方では「春発」と呼ふ。

3.「春無」長五六尺幅二尺、器物を圈いたりする。南方北方と もに「春㭷」と呼ふ。

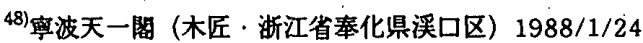

${ }^{49)} \mathrm{Emms}$ も中国の木匠はイギリスの木匠よりよくタテオノを使う.

と指摘。前揭 [Emms、1937.3. p96]

${ }^{50)}$ 上海市豫图（木匠・江葆省常熱）1987/4/15

51)前揭 [竹中大工道具館、1994、p17]

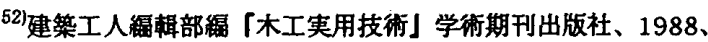
p75.76

${ }^{53)}$ 上海豫國の〈劇台〉の《楼座)の製作に使用。

${ }^{54)}$ 上海市豫園（木匠・江蘇省常㷫）1987/6/28

55)金属を打たないことにつては前揭［劉殿样、1985、p24-25］ 及び前揭［ホンメル、1992、p375］も記載。

56)北京故宫（大木·河北省新河） 1988/6/29

57)前揭［建築安装技工学校土建木工工芸学秙集組、1981、p33］

58)管見のものは北京市内 (木匠 ·河北省溷州) 1988/6/28。竹中 の調查に挄いては山西省五台山で観察されている。前揭 [竹中大 工道具館、1994、p14]

59)北京故官（大木·河北省新河） $1988 / 6 / 29$

60) ホンメルは江西でカナツチ型片手持ちのものと、㮩桶職人の短柄 袖付のヨコオノを観察している。前揭 [ホンメル、1992、p376]

61)前揭 [竹中大工道具館、1994、p14]

62)前揭［ホンメル、1992、p377]。および前揭 [Alfred Emms， 1937.2.1937.3.1937.4]

63)前揭 [姚承柤、1986]

64)前揭［王寿華、1985、p47]

65)河南省信淂市長台関楚墓から出土。長さ $27.8 \mathrm{~cm}$ の木製柄も完全 に残存。竹简䌘作の工具と考えられている。前揭 [林絷晋、

1981、p100 圖版拾伍]

66)前揭［趙繼柱、1981、p159]

${ }^{67}$ 北荘漠基の後漠末と思われる盜掘穴付近から出土。河北省文化 局文物工作隊「河北定県北荘漠基発掘報告」「考古学報」赭 34 冊、2期、pp127-158、1964.12、pp152-153

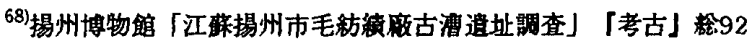
(1期)、pp55.61、1992.1、p56 p57 图四:19

69)吉林省博物館輯安考古吉林輯安県鎮家村発現金代文物」「考 古」総87期、pp616-617+629、1963.11.p617 图1：7 図版陸

${ }^{70)}$ 木船は1352（元至正12）年を下らないと推定される。磁県文化 館「河北磁県南開河村元代木船発掘简報」「考古」6期、 pp388-399+图版捌、1978.11.p394 图10:3

${ }^{71)} \mathrm{J}$. ニーダム「中国の科学と文明 10巻」思索社、1979、p336

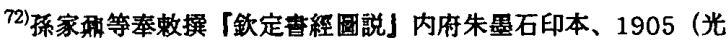
緒31）、巻十七 22 (東京大学東洋文化研究所所葴)

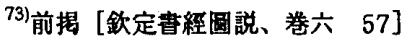

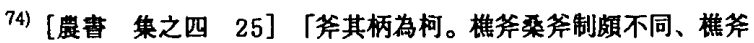

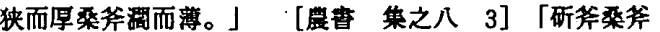
也。…區而刃興椎条不同。」王楨「農書」山東布政司刻刊 
本、1530 (明嘉靖9）現存する最古の版本（内閣文庫所藏）

${ }^{75}$ 王次（1565-1614）「三才回繪」上海古籍出版社、1985、器用 十一、巻 7、1609（明萬歴37）年刊行の上海図者館本影印本。

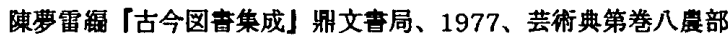
第423冊 38、1725（䔨正3）年刊行の影印本。

${ }^{76)}$ 天工開物、巻中 46] 末応星〔天工開物】上海古籍出版、 1988、1637 (明崇楨10) 年の初版本影印本。

${ }^{77}$ 河工器具回説」南河節春蔵板、1836 (道光16)

(東京大学東洋文化研究所图書館所藏) 嶙鹿（1791-1846）は北 京に半效園を営んだことで知られ、Hummelによれば黄河の河道管 理改修を担う江南河道皖督（1833-42）を勤める。

Arrhur W . Hummel :Eminent Chinese of the Ching Period,United States Government Printing Office 1943、pp506-507

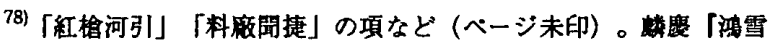
因椂圖記」北京古籍出版社、1984、1849（道光29）年刊行の揚 州刻本影印。

79)前揭 [河工器具圖説、巻三 16]

80) [魯㺲程 巻一 18］ 位砍〉の図

81) [瀂科経 - 1] 「起工架馬」「歩柱安放馬上」 [魯玨経 巻一 2] 「木馬殺」

82) [蟹环程 巻一 16] (平砍)の図

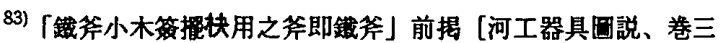
$16]$

84) [魯珻経 巻一 20]

85)嫨代の夕テォノについては林氏がッチとしての使用を指摘。前揭 [林巳奈夫、1976、p286]

${ }^{86)}$ 山東省博物館管理她秷「山東文物選集」山東省博物館、1959、 説明p11、写真 括本p103

87 林氏俚カナツチと考えている。前揭 [林巳奈夫、1976、p288] 前揭 [山東省博物館管理処䋹、1959、p103] の写真が不鲜明な

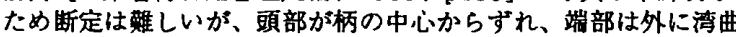
していること、「考工記車人」で車輸作りの基準にオノが用いら れる点などからタテオノと考えられる。「考工記車人」は王雲五

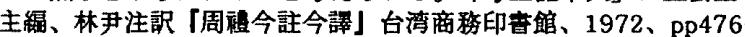
477を参照。

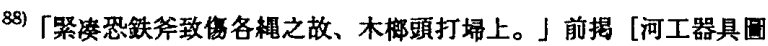
説、巻3 16]

89)図は［魯㺲経巻二 22］「一字棹式」は［魯班経 巻 二21]にある。

90)王世衰「明式家具珍巷」文物出版、1985、p 37.38

91)板器式][鰫玻経 巻二 28]

${ }^{92)}$ 伊藤平左工阴「建築儀式」彰国社、1959、p55

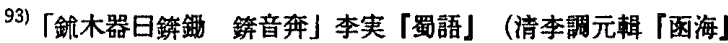

第十三函、第八怢） 1881.82 (光緒7-8）、2

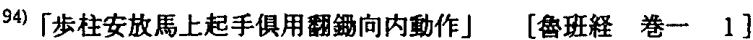
[魯昨営造正式 18]の「起工架馬」にも「推匠人起工格式 歩柱安放馬上起手動作」とあるが、工具名は記されていない。

95) 「寺観奄堂㾰宇式 . . 左手執六尺右手拿䆑」图も同ベージ。

[魯班経 巻一 32］「建造禾會格. . . 左避立執爷向内斫 入」[魯伍経 巻二 4] 図は［魯班経 巻二 5]

96)白川静「字統」平凡社、1984、p71

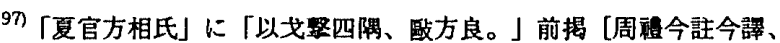
1972、p324]

98)前揭［伊藤平左工阿、1959、p 161-162］

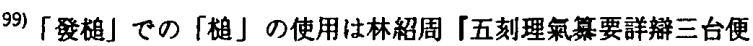

賞通意正宗」 1637 (明崇楨10)、巻十三 2-3等に見られる。 「上梁」で「木限頭」の使用については、前揭 [Ruitenbeek、 1993、p110]に見られる。また「魯般営造正式」、「魯玨経』 の「上梁文」には「一㹂租翠透天門」の句があり、「上梁」に ツチを用いたと考えられる。［魯琵経 巻一 9］及び［魯般 営造正式 6]

100)前揭［伊藤平左 $x$ 門、1959、p $65 \cdot 71]$

101）「附碳烈法、匠人不仁而主人待之或薄則画成人物厤而詛之藏于柱

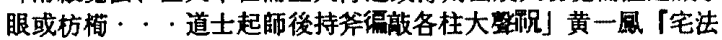
全書」明刊、下 75.76 (「相宅造福全声」所载 内閣文庫所藏)

102) 等達峰「中国営造民俗中的上梁儀式研究」「国風」第2巻、第 6 期、pp1-18、1989.10. pp9-11

103)前揭 [Ruitenbeek、1993、p141]

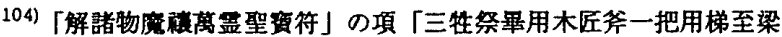
枋各處三下遂念天開一呪」[秘訣仙機 16]

105)雷発達（1619-1693）は宫殿の絵图模型「様式雷」で知られ、 工部営造所の長理を勤めた。朱啓铃「哲匠録」「中国営造賲刊」 pp82-137、第4巻、第1期、1933.7. p84

（1994年12月10日原稿受理，1995年 4 月24日採用決定） 